\title{
On the meaning and novelty of impressionistic thinking on the example of Russian animalistic sculpture of the late XIX - early XX centuries
}

Summary. This article dwells on consideration of Russian animalistic sculpture of the late XIX - early XX centuries, representing a new plastic thinking and figurative system. This important historical period, that was marked by the development of Russian impressionism in sculpture, had a fruitful effect on animalistic plastics. By this time, the animalistic sculptural genre, which had fully established itself in its stylistic figurative system, at the turn of the century had experienced something new. We are talking about fresh way o thinking and look as at the plastic itself as at the object of the image. Sculpture has never been of such a «dynamic» quality and the animal image in sculpture has never been perceived so fleetingly before. 3Here is a figurative concept that encompasses all the fine lines of the semantic significance of animalistic plastics. It is characterized, first of all, by the fact that the image begins to acquire greater symbolic ambiguity and meaningful subtlety. The main purpose of this article is to пTo track the meaning and the novelty of impressionistic thinking in animalistics by the example of the works of A. Golubkina, P. Trubetskoy, N. Andreev, V. Domogatsky. It's noted that the novelty of the impressionistic thinking in animal sculpture is based on a «movable» plastic and «metamorphoses» impressionistic thinking in animal sculpture is based on "movable" plastic and "metamorphoses" of the sculpture shape and the process, which takes place in animalistics, reflects a significant side of the development of Russian sculpture of the late XIX - early XX centuries, opening up new perspectives and solutions.

Keywords: Impressionism, concept, animalistic sculpture, material, plastic, image, style, animal, thinking, artist

Introduction. Russian impressionist sculpture of the late XIX - early XX centuries is a short-term phenomenon, but a very fruitful one. It brought us new interesting options of plastic thinking. Our conversation will concern the animalistic image, its interpretation. The animalistic character appeared among the works of famous Russian sculptors of that time: A.S. Golubkina, P. Trubetskoy, V.N. Domogatsky, N.A. Andreev, who were prominent representatives of impressionism in Russian sculpture of the turn of the century. The appeal to the animalistic image for was quite natural for them, probably even 


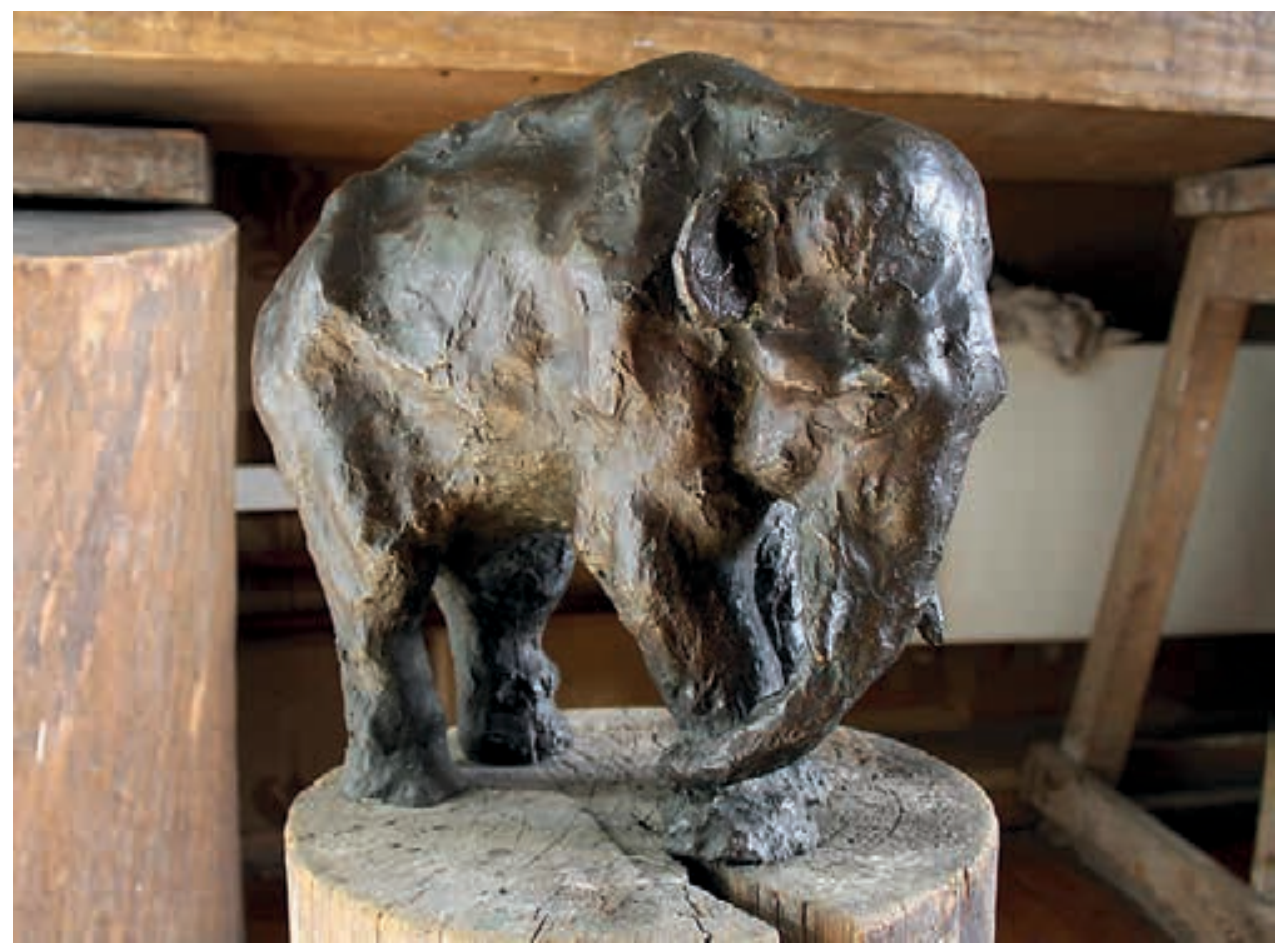

Ill. A.S. Golubkina. Elephant. Tinted gypsum. Vasnetsov Brothers Art Museum

logical. Impressionism, which has changed the worldview and broken the old academic concept of the image, was easily modeled on animals in the minds of sculptors. Beasts and birds began to be portrayed in a quality in which they had not previously been seen, namely, as carriers of mobile spiritualized matter. This «spiritualized matter.», which took place in different eras, has generated a certain interest in animalistics among as Russian, as foreign researchers. The authors has been eagerly discussing the history of world animalistic, from antiquity to the present day. David Aftandilian [Aftandilian, 2007], Gordon Lindsay Campbell [Campbell Gordon, 2014], Hope B. Werness [Werness, 2006] note its importance and the role that animals played in society. They talk about the symbolic essence of animals and birds in various world cultures and point at an everincreasing problem associated with the interaction of humans and animals. Thus, Margo De Mello [Mello, 2012] talks about these relationships, determines the place of animals in the social and cultural worlds, believing that this rapidly growing field of research is relevant for modern society. Continuing the conversation, Roni Grén [Grén, 2017] considers the importance of the animal in the theory of modern art, focusing not that much on their image as on understanding their essence in the modern era. Nowadays, foreign and domestic researchers emphasize the need in studying this art, representing unchanging classic patterns. 


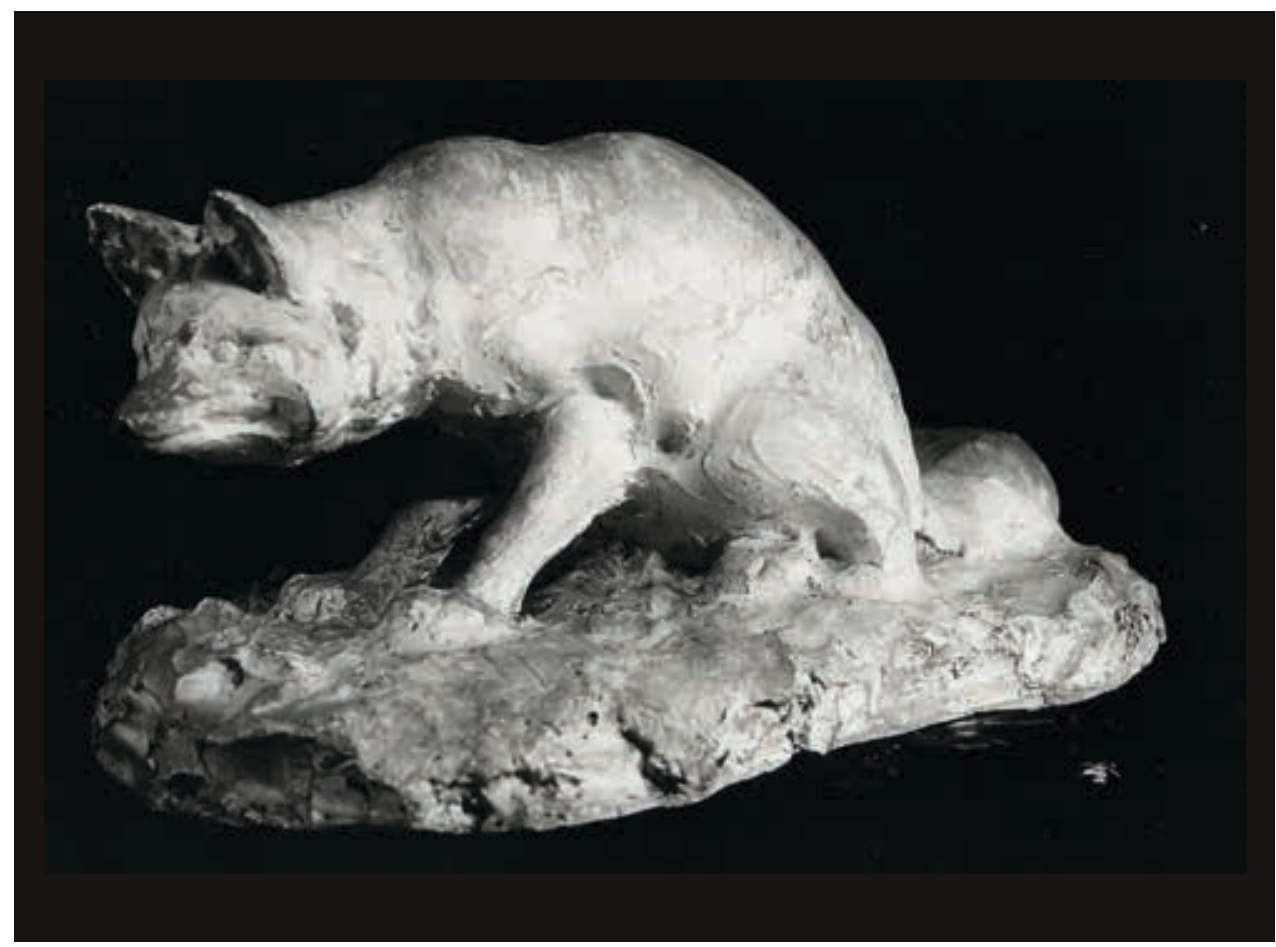

Ill. N.A. Andreev. 1903. Fox. Gypsum. State Tretyakov Gallery

Russian authors willingly wrote about artists and their works of the New Age, evaluated the animalistic genre as the perspective one, interacting with other genres and the artists' works as the worthy ones of attention. Thus, V. Petrov [Petrov, 1864], A. Andreev [Andreev, 1857], D. A. Rovinsky wrote about the art of «animal painting» of the XVIII century as a special «kind», about artists who reached the top of creativity. [Rovinski, 1985]. In the late XIX - early XX centuries, due to the emergence of art history, interest in various topics of fine art, collecting works, arranging auctions and the activities of art museums, questions of the creative personality of artists and various ways of interpreting the image of an animal began to be raised more and more often. At this time, books about animal artists, articles in compilations, magazines and dictionaries were published. Thus, works of animal sculptors: P.K. Klodt [Pertsov, 1888: 183189], N.A. Liberich [Silkowski, 1892], were considered in historical magazines: «Art Journal», «Russian Art Archive». Publications marked by ther interest in the aesthetic side of the works of masters, a desire to evaluate their creativity, a will speak about an important feature of the work of an animal painter - drawing from a living nature. Since the beginning of the 20th century, the result of the participation of animal artists in exhibitions has been numerous catalogs. The 1930s and 1950s were characterized by the appearance of the first catalog of the exhibition of animal artists (1939), which had taken place at the Moscow Zoo, dedicated to the 75 th anniversary of it. The first publication 


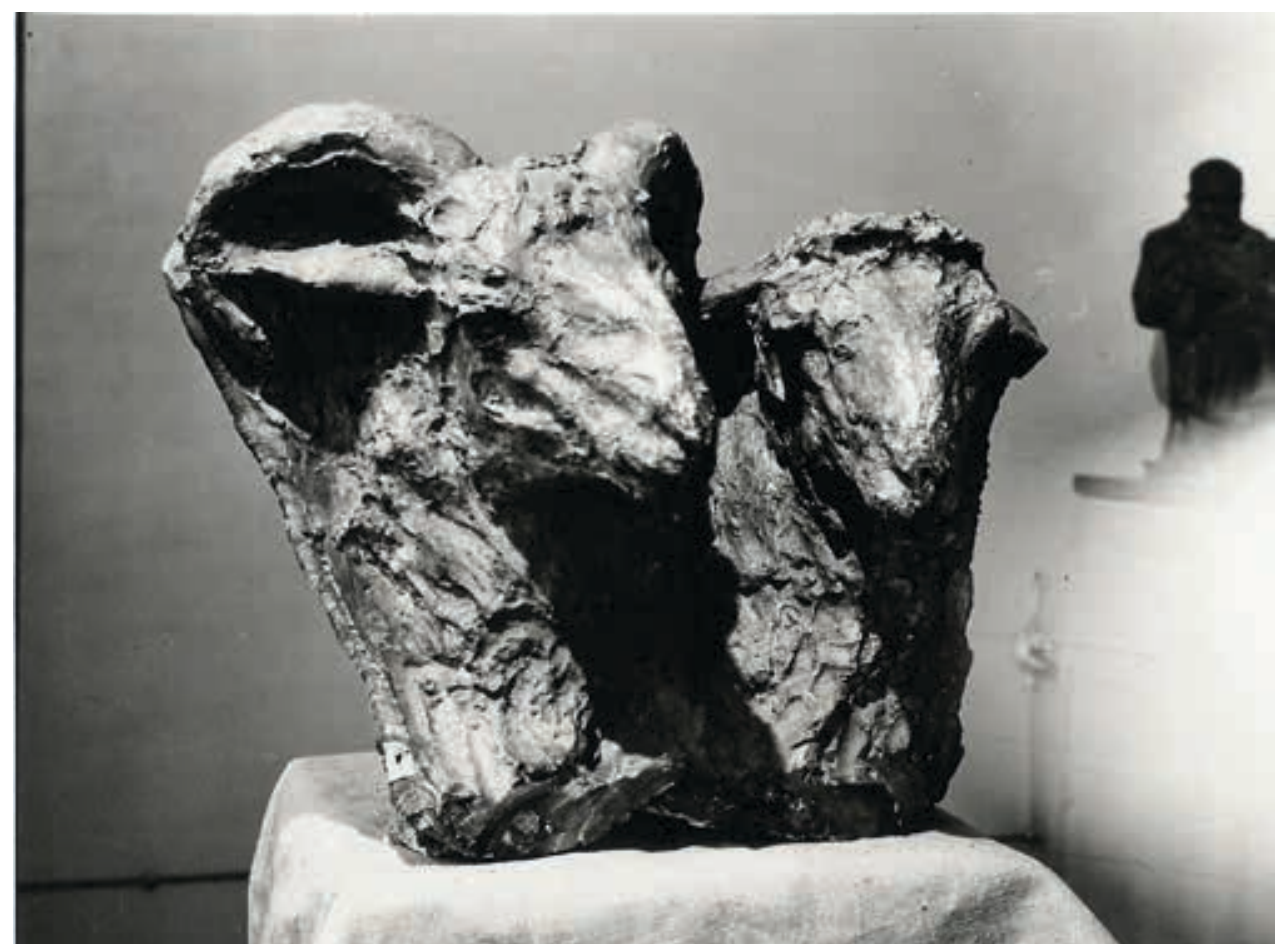

Ill. A.S. Golubkina. 1913. Rams. Gypsum. State Tretyakov Gallery

of B. Alekseev about this exhibition in the «Art» magazine [Alekseev, 1939: 127-131], who noted the fruitful development of the genre in the field of sculpting. Subsequently (1960-80s), catalogs of animalistic exhibitions will become a tradition, which clearly emphasizes the strong interest among artists and the public as an objective reality. The issues of impressionistic plastics don't have such a wide coverage in the literature. Nevertheless, the creative personality of A. Golubkina, P. Trubetskoy, S. Konenkov and other masters is considered in the book by I. Schmidt [Schmidt, 1989.] The author sees in impressionism a consistent and evolutionary beginning. He is tend to think that impressionism was the result of a realistic reflection of the life of the preceding time, showing a logical link in the historical process. In this regard, it's worth pointing out the monograph by O.V. Kalugina, who deeply explores the work of the famous sculptor of the late XIX - early XX centuries A.S. Golubkina in the context of this era [Kalugina, 2006]. Despite the fact that A.S. Golubkina wasn't an animalist in the literal sense of the word, her few animalistic works, just like the works of N.A. Andreev, V.N.Domogatsky, is very revealing. The intuitive experience and feeling of the image, characteristic of the artist's method led to the formation of a new look at animals that are emotionally close to a human, that look that will receive a bright implementation in the work of the animal artist of the XX century V.A. Vatagin. In her turn, L. Trifonova wrote about the rich plastic possibilities of impressionistic sculpture [Trifonova, 2002.]. 


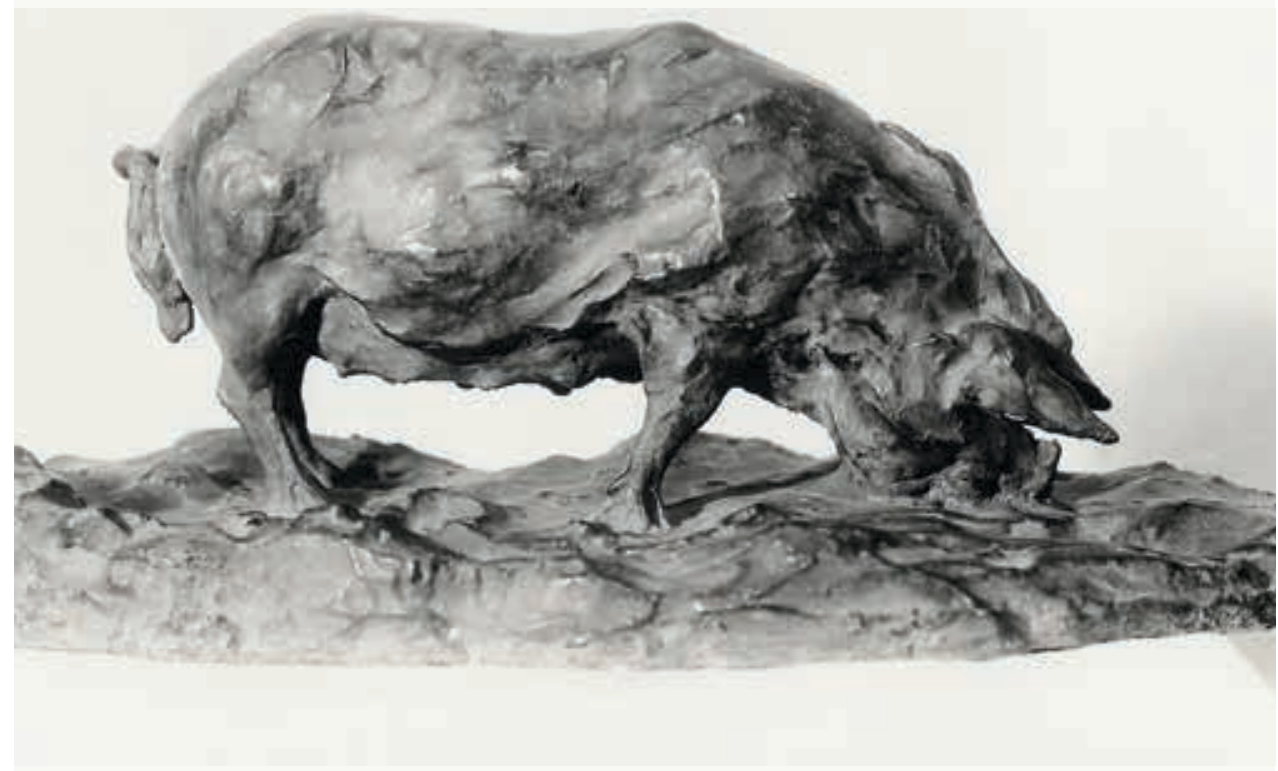

Ill. V.N. Domogatsy. 1909. Pig. Tinted gypsum. State Tretyakov Gallery

Researchers are unanimous regarding the importance of impressionism as an essential phenomenon in the development of Russian sculpture. Describing the work of famous masters, they note a new look at plastic, which formed a new direction. It's significant that Golubkina, Trubetskoy, Andreev and others, expanding the boundaries of the figurative understanding of the portrait, the genre, realized their creative credo in animalistics as well. Christopher Payne [Payne Christopher, 1986.] in his book «Animals in Bronze: Reference and Price Guide» mentioned Trubetskoy as a talented animal artist, whose name extends beyond Russian art. However, this aspect wasn't properly reflected in the literature and yet impressionism in animal sculpture is an unusual, «living», national phenomenon. In this regard, a more comprehensive analysis of animal works by Trubetskoy and other masters who worked in this area is needed to give a holistic picture of the development of Russian sculpture of the late XIX - early XX centuries.

We're interested in impressionism as a semantic category and how «meaning» is realized in animalistic sculpture with a specific character. A new meaning brings a rise to a new concrete form. The goal of this article is to trace these tendencies of the turning era.

As the most appropriate solution of this goal, we'll single out the method of art history analysis, which involves a historical-problematic approach (the problems of impressionistic thinking in animalistics) and historical-artistic, which allows to identify the structure of the artistic image. 


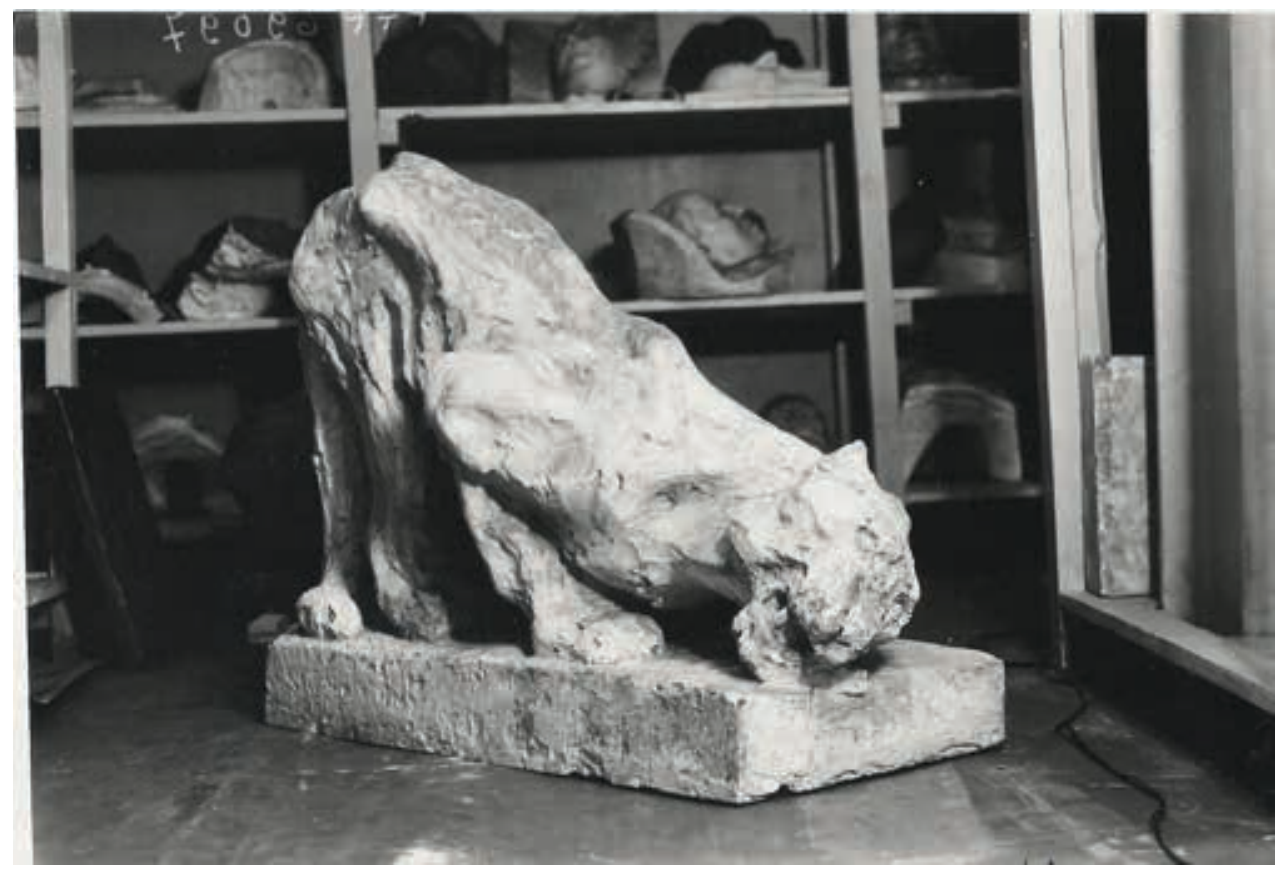

Ill. I.S. Efimov. 1915. Tiger. Gypsum. State Tretyakov Gallery

If you understand that impressionism is a movement, mobile thinking, then the semantic category will especially be mobile, based on nuances and subtle meanings. This is what the impressionistic animalistic plastic was like. In this regard, we consider three questions. The first concerns the sculptural meaning of impressionism and its implementation in animalistic sculpture, the second is targeted on the reflection of the novelty of impressionistic thinking, the third explains the animalists' preferred choice of the sculptural model.

\section{The image of an animal in Russian animalistic sculpture of the late} $X I X-$ early XX centuries

To understand the essence of animalistic at the turn of the century, let's look into history. Animalistics as a kind of art was formed in the XVIII century on the wave of the general upsurge of Russian culture and new trends in secular art. In Peter's time, great demand and interest in the material sides of life, their study led to the first explanations of nature, which was reflected in the collection of natural objects and sketches of them. They made up the collection of the early science museum - the Kunstkamera in St. Petersburg. Then, when masters-animalists were designated, and these were foreign artists (the first one among them was German J.Grooth), animal art became the one that's 


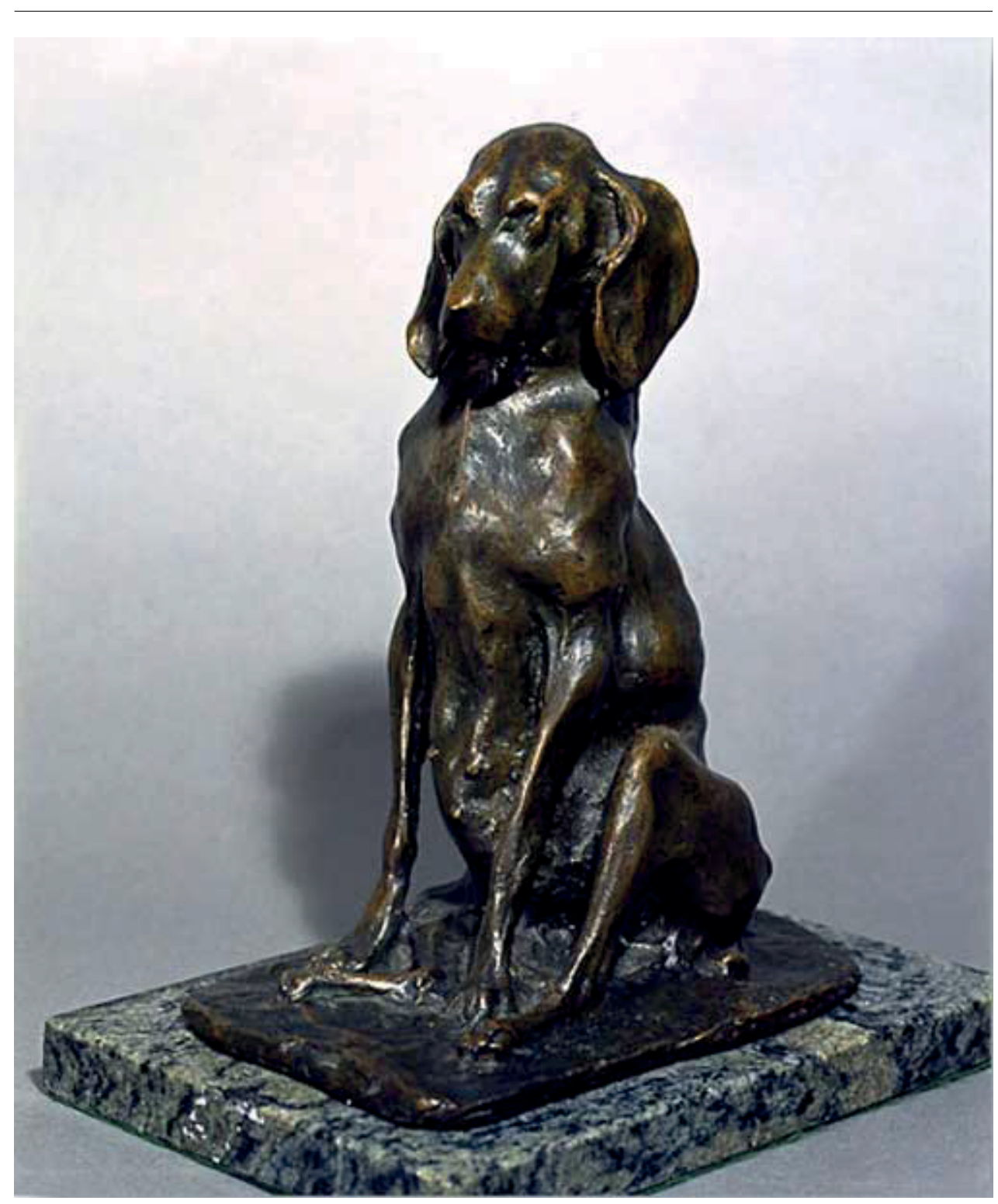

Ill. Paolo Troubetzkoy. Dog.The beginning of XX century. Bronze, stone

in demand. Hunting themes, still lifes with animals and the depiction of various animals and birds «through forests, coppices, swamps and lakes and related objects before hunting» [Wrangell, 1911.] reflected the preferences and tastes of society of that time. At the same time, animalistics began to turn into a genre form. It had already been an independent «genus» of art in the general established genre system of the XVIII century.

Stepping into the new XIX century, the genre found interpretation in the «equestrian» image (the image of a horse) in different thematic versions. For the first time, one 


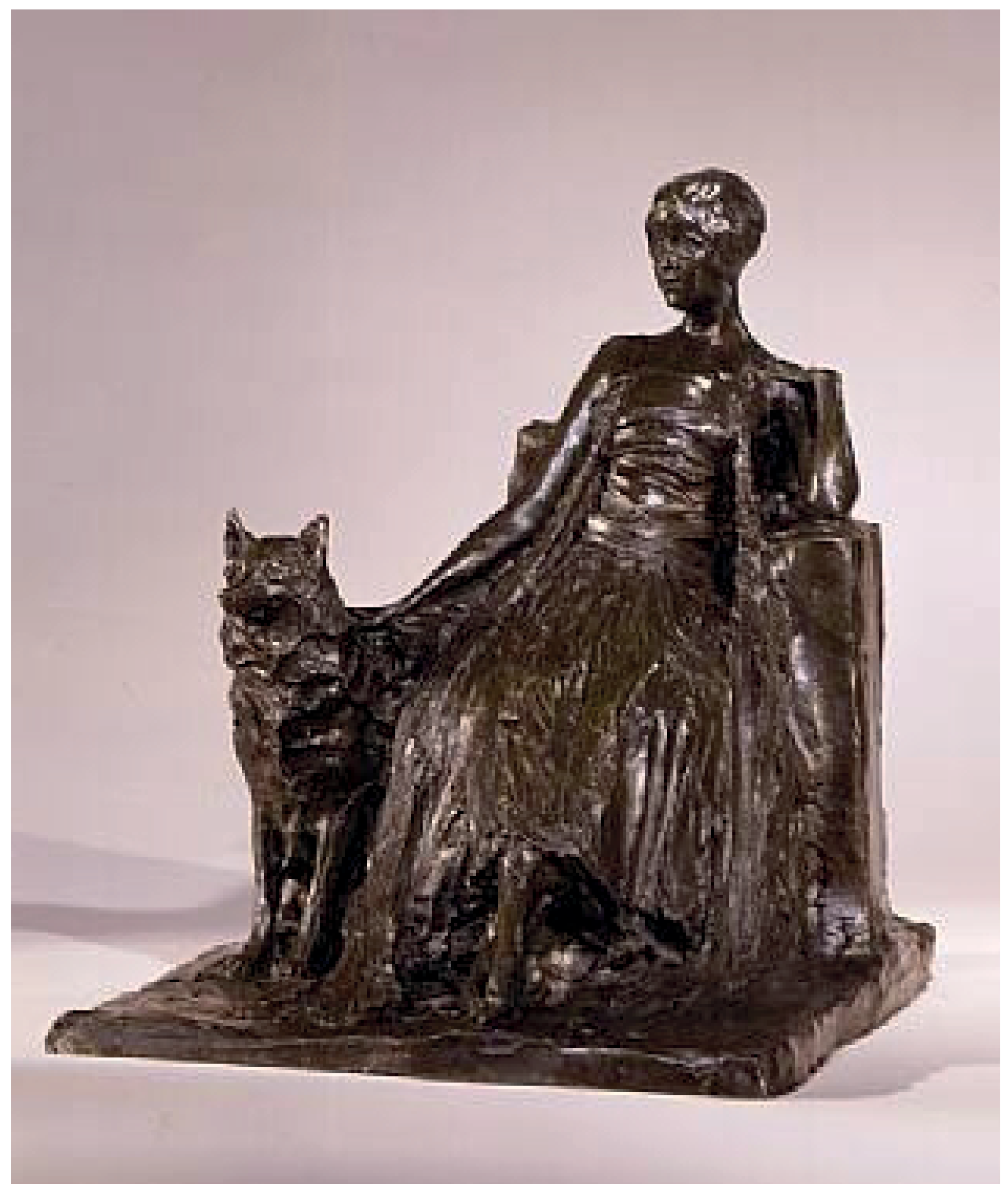

Ill. Paolo Troubetzkoy. 1921. Margaret Draper with a dog

character - the horse became the subject of public interest and the object of the image of animal artists. It's obvious that the historical stylistic epochs of the XVIII and XIX centuries formed the qualities of the image and all its attributes. If in the early XVIII century the illusory, accurate pictorial depiction of animal scenes was intended to attract the attention of the viewer, to enchant him with its variety, exotic nature, then in the XIX century a completely different idea was released - to show the animal in the 
service of human. There is no coincidence that this century is called «horse culture» ${ }^{1}$. From a baroque, then classicist decision to realism - this is the way of interpreting an animalistic character.

And what did the turn of the centuries give, in what form did animals appear at the end of the XIX and beginning of the XX centuries, what an assessment did they and the art of image get from human?

The first thing we pay attention to is the choice of models. Artists aren't tend to depict hunting animals - participants of hunting scenes with attributes corresponding to it, as was the case in the bronze sculpture of the second half of the XIX century by E. Lansere, N. Liberich, A. Ober. And the horse wasn't so common in their compositions. The explanation for this is simple. These characters reflected the tastes and preferences of bygone eras and the corresponding sculptural style. The reliability of the captured motive by means of a carefully modeled bronze form determined the values of the works of those years.

Among the works of artists of the late XIX and early XX centuries we will see domestic animals; dogs, pigs, cows and residents of forests and fields of central Russia: foxes, bears, hares and others. The choice is dictated by a new view of a person on an animal, as a creature with its own behavioral characteristics outside its hunting affiliation. An animal is an emotional character, therefore it's interesting and there is no need to look at it from a narrow perspective of a hunter or natural scientist, but it's worth looking through the eyes of only an artist and an artist-humanist. In addition, animals and birds that live next to humans, not mentioning pets, give such an abundance of material. It's logical to assume that the new character required a different approach. However, the features of the plastic wasn't set by the character but by a fundamentally different method of work, which consisted of shifting the emphasis from solid material to stucco molding, and, accordingly, the hand was seen as the main tool when «the factor that determines the texture - the artist's personality, his direct psychophysical imprint plays a bright role» - as V.N.Domogatsky noted, and it's clear that it will be brighter here than when it is directly (through the tool) in contact with the material, during cutting and carving ${ }^{2}$. In each of these moments, it was important to capture the closest impression of nature, reality to fix the trepidation of this life. Impressionism gave a new impression with its new method of work and a fresh look at the material.

In the system of impressionistic plasticity, such a mobile creature as an animal turned out to be a suitable object. The value of a single moment, its transitional state was taken by sculptors as the basis of their plastic decisions. A new solution to animalistic compositions attracted, refreshed perception. This is the essence of the sculptural meaning

1. Pertsov P. P. Sverchkov v Prilepskom sobranii. Stat'ya. Butovich YAkov Ivanovich. Materialy k sborniku o hudozhnike Sverchkove Nikolae Egoroviche [Crickets in Prilepska meeting. Article. Butovich Yakov Ivanovich. Materials for the collection of the artist Sverchkov Nikolai Egorovich], 1922-1925 г. RGALI. F. 710. Op.1, ed. xr. 14. 39.

2. Article by Domogatsky V. N. Faktura i metod ee issledovaniya [Texture and method of its investigation], OP TG. F. 12. ed. xr. 43. 13. 


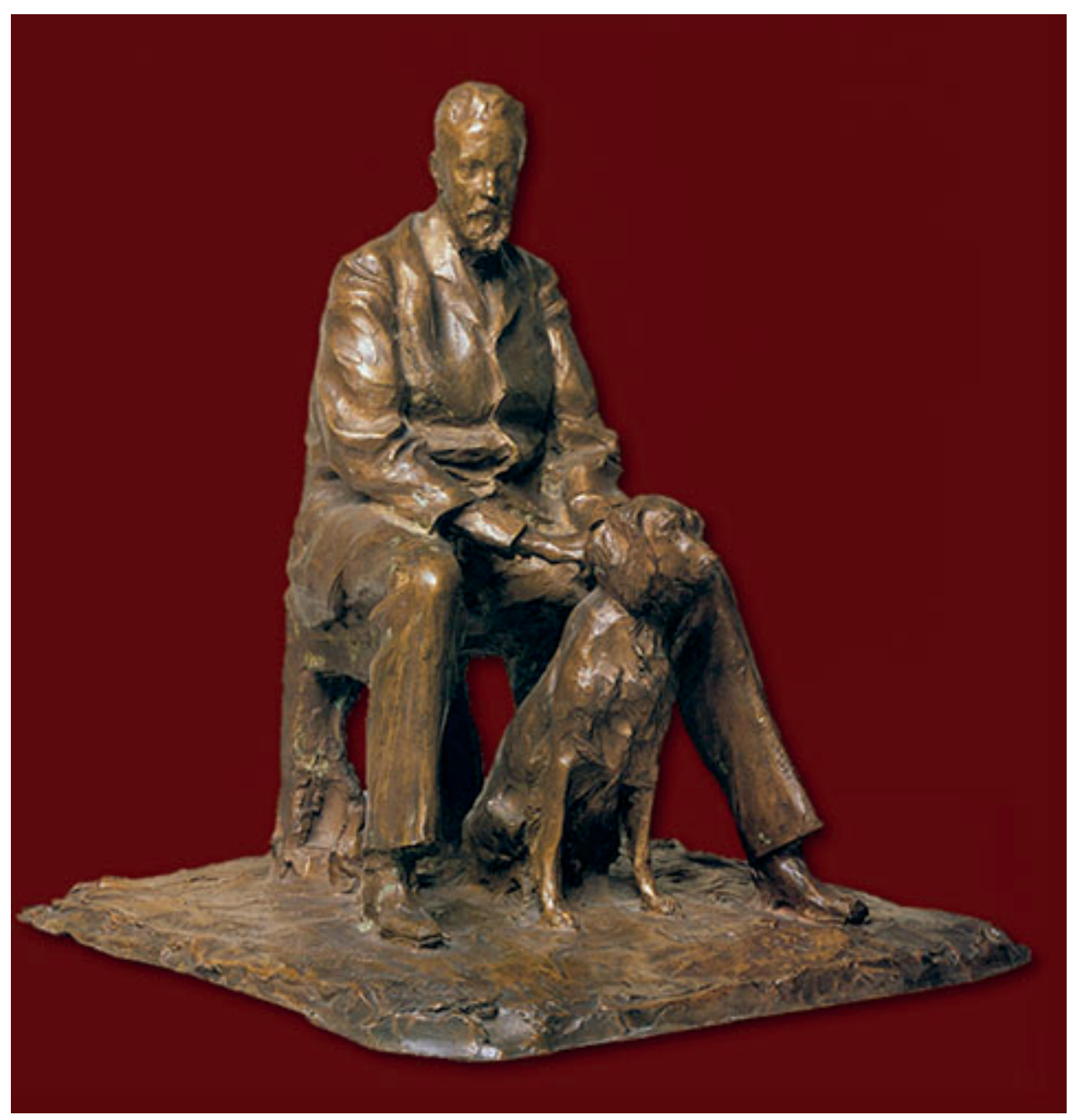

Ill. Paolo Troubetzkoy. 1901. Sergei Yu. Witre with a dog. Bronze

of impressionism in general, which arose as a necessity, the need to update the language of sculpture, which by this time had still been cultivating academic standards of beauty in a number of its samples. As for animalistics, the impressionist perspective allowed us to look at the animal in close immediate perception, almost in a emotionally personal one. Flowing, «movable» plastic form of the material gave a variability of the state of a living being, accurate in a short period of time and the method of soft plastic modeling gave a rise to more and more associations. And these behavioral moments, built on the subtle movements of the gaze of animals, the relaxation or tension of their bodies, their heads turn etc., found an organic embodiment in sculpture. If impressionism as a way of thinking became a large-scale phenomenon in French painting, then in Russian art it took 
place, first of all, in sculpture, which opened up new qualities of interpretation in this art form and importantly served to formation of the animalistic genre of the XX century.

Let's consider the visual structure of some works and try to identify those properties of the importance of impressionistic thinking in the view of the masters on the animal.

We note the chamber almost etude character of the works of Trubetskoy, Andreev, Golubkina, Domogatsky. These are small easel works, made mainly in bronze, gypsum. Bronze as an old traditional material among the impressionists appeared in its new expressive properties. It fixed all the fluid moments of the form. The reflecting surface of the metal, glare and depth of the shadows created the effect of mobility of nature. On the contrary, gypsum has a matte structure, but was also a typical material, since it characterized the stucco surface, the volumes of distinct hollows and bulges.

Let's name the works of P. Trubetskoy from a number of genre-animalistic: «Moscow cabman» (бронза, 1898) «Angelina and the Wolf» (bronze, 1909), «A Girl with a dog» (tinted gypsum, 1897), «O. J. Yakunchikova on a horse» (bronze, 1913) and others. (IIl. $1,2,3$ )

In these compositions human and animal are portrayed together, what is very important for Trubetskoy, it characterizes his perception of the world. In this unity, he sees the concentration of the main things, he talks about the attachment of animals to humans and, more importantly, about the human understanding of the animal. In his animalistic works («Dog (sitting setter), bronze, 1898-1899, «Horse with a foal» 1899, «Siberian Laika» 1903, «Horse under a saddle» 1898) human isn’t portrayed but presents invisibly. This is an important point. After all, human is the one who is first of all responsible for the fate of animals. V. Bulgakov was right when he saw the «idea of Trubetskoy» in the understanding of animals as sentient beings. According to the sculptor, if «they're properly educated and freed from fear of human, then they will perfectly coexist with people and with each other.». [Bulgakov, 1969.]. The loyalty to vegetarianism, the keeping wild and domestic animals in the workshop is also explained by the fact that Trubetskoy deeply admires the «smaller brothers» and, in fact, he's the founder of the new «concept of nature» in its environmental sound, which will sound in full volume in XX century. And what about plastic and impressionistic expression in sculpture? The flowing plastic mass, complemented by the play of light and shadow on the surface of the sculptures, reflects the shades of emotions. «Lyricism» in sculptures of Trubetskoy is of a special nature, somewhat sad and incredibly reverent, is only akin to the landscapes of I. Levitan. Called to reflect the nuances of the mood, it's realized in sculpture according to its own laws of shaping. The impressionism of Trubetskoy isn't an end in itself, his modeling and methods of figurative characteristic are directed in one direction - to get closer to a comprehension of the living, almost the elusive essence of nature. Contemporaries saw this rational seed in the work of Trubetskoy, in particular, I.I. Tolstoy wrote in a letter to B. B. Golitsin: «The artist Trubetskoy, undoubtedly, it seems to me, has a remarkable talent, he with a special success conveys the nature in small figures, interpreted in sketches: in them he remarkably and vividly grasps 
the pose, resemblance and even expression...». At the same time, he sees «a talented painter who was known for sculpture, not as a specialist sculptor» ${ }^{3}$ in Trubetskoy. A. Kamensky believed that the term «picturesqueness» in relation to Trubetskoy's works can be applied only in relative measure: the master doesn't really polish the surface of his sculptures, makes wide use of chiaroscuro, its vibration, its transitions and dynamic effects. But the analogy with painting here is only external: all these methods have a purely plastic nature; they don't break the three-dimensional stereometry of sculpture but only expand and enrich the traditional repertoire of its expressive means» (Kamensky, 1974.). The master in his turn said: «I love life that's not dried up by scientific speculation» (Pavel Petrovich Trubetskoy, 1991.). «The Absence of dryness» explains Trubetskoy's choice of the small size of the sculpture and live plastic, as if it was created in front of the audience.

The perception of the pictorial language in the sculptural composition of the turn of the century is a quite natural process. Firstly, the sculpture of impressionism saw this as a widespread need for updating the plastic language, which at the turn of the century became a necessity. Secondly, the moving picturesqueness of the masses, bringing emotionality, corresponded to the animalistic image, facilitated the penetration into the subtle world of feelings. Such interaction was indicated by O.V. Kalugina». [Kalugina, 2006.], speaking about works that the audience perceived as unusual but modern and spiritually close due to the openness of the sculptors to the influence of other forms of art.

A movable sculptural mass that gives birth to a sense of life of nature can be observed in the works of V.N.Domogatsky («Cows in the herd» 1903, «A Pig» 1909, «Calves» 1900s all bronze, «Chickens» 1900s gypsum). And also among N.A. Andreev's works («A Fox» 1903, gypsum, «Goat's Head» 1910-11, gypsum, «Bound Lion»1916, terracotta). (Ill.4,5)

Having passed the school of S. M. Volnukhin at the Moscow School of Painting, Sculpture and Architecture, the masters understood the principle of «real-life realism» and reflected it in the plastic of impressionism, finding the opportunity to show the animal in a direct form when the image was born instantly. The lack of preliminary sketches, all the successive stages of work accepted at the academic school - this is the principle of impressionistic perception, giving rise to an image on the go without any repetitions.

Andreev's process of birth of a sculptural image lies entirely in the plane of nature and is determined by the breadth of its entire line. Here is what the student N.P. Gortynskaya wrote in her diary: «Our classes began with modeling from a living nature in a large bright classroom. On a high stand there was a cage with a rooster and chickens, then they were replaced by geese, a monkey Yashka, a fox, a baby bear .... Nikolai Andreyevich usually painted with one wide, plastic line, covering the nature from head to

3. Tolstoy Ivan Ivanovich (1900-e). Pis'mo Borisu Borisovichu Golicinu [A Letter to Boris Borisovich Golitsyn] Petersburg. OR RNB. F. 781,. ed. xr. 650. 
toe, quickly, vigorously marking chiaroscuro with charcoal, slightly rubbing it finger the picture was expressive and voluminous» ${ }^{4}$.

The same wide plastic line can be observed in a fox listening and looking into the distance (1903), more tremulous in the head of a baby goat (1910-11). In the animals of Andreev there is no tender complicity and love for human, as was observed in Trubetskoy, there is more than a purely primordial nature. The psychologist's perspective, which was so originally and fully expressed in Andreyev's famous «Leninian», was projected onto an animal. In this regard, we highlight the early work of I.S.Efimov «The Tigress» (1915, gypsum). (Ill.6)

It seems to be the personification of the emerging physical and energy strength, it's their symbol, the structure of animal flesh, so spontaneously revealed by the keen eye of the master. The plastic of the springy, strong body of the tigress, as if it's preparing for a jump, is more than impressionistic in the traditional sense of the word. We find something similar in the works of A. Golubkina: «Dogs» (1894,), «The Elephant» (1901, bronze), «The Monkey» (1901), «The Fox» (1902), «Cats» (1909), «Horses» (1909), «The Bird» (1910), «The Ram» (1913, gypsum), «The Seal» (1913, gypsum). (Ill. 7,8)

They are also complex in their emotional coloring and expressive in plastic form. It seems that the plastic mass is over-crowded with animals and they are ready to break it out and this feeling is created with their external static. The excitement of the artist, as in other works by Golubkina, is palpable. J.N. Verkhovsky in poetic form reflected the creative impulse of the master, as if contemplating the course of this process: «The rough hands that were throwing lumps of green clay, caressing them with a gentle touch of fingers; the fabric of the finest efforts was crushed with a single blow... $\rangle^{5}$. This is what Golubkina wrote, sharing the secrets of mastery with students: «When you work, you need to feel it, and when you tear off something wrong from the clay, you wound it ... You need to discipline yourself so that the thought you want to express in the clay, without losing its freshness, will be finished and every extra touch makes it not that fresh and trampled» ${ }^{6}$. Z.D. Klbukova accurately characterized the manner of Golubkina, who «ends the thing with a psychological throw» ${ }^{7}$. This is the whole essence of her sculptural vision. "The psychological throw» is a dynamic mass, and Anna Semenovna often compared this dynamics with the dynamics of an ongoing locomotive» - a sculptor Z.D. Klobukova noted. N. J. Simanovich-Efimova gives an equally accurate description: «The sculpture by Anna Semenovna isn't a sense of touch, it's a vision. Anna Semenovna wasn't a person who was aimed to touch. She was the watching

4. Vospominaniya N.P.Gortynskoj o skul'ptore N.A.Andreeve [Memories of Nikolai.P.Gorchinskiy about the sculptor N. And.Andreyev], OP TG. F. 86, ed. xr.718 .2,5,34.

5. Verkhovsky Yu. N. Vayatel'. Stihotvorenie [Sculptor. Poem], RGALI. F. 202. op.2. ed. xr. 279.

6. Vospominaniya skul'ptora Z.D.Klbukovoj ob A.S.Golubkinoj [Memories of the sculptor Z. D. Klobukova about A. S. Golubkina], 30VII (1949). OP TG. F. 37.ed.xr.53. 10, 11.

7. Vospominaniya skul'ptora Z.D.Klbukovoj ob A.S.Golubkinoj [Memories of the sculptor Z. D. Klobukova about A. S. Golubkina], 30VII (1949).OP TG. F. 37. ed.xr.53. .25. 
one ...» ${ }^{8}$. «When you look at an object, - the artist said, - let it hit you first in the eye, then in the heart, and then in the head» ${ }^{9}$.

This triad of perception, described by the sculptor, reveals the essence of her figurative thinking, the method of work and attitude to the model. Human and animal are the whole world with their own world order, and animals in the concept of Golubkina are initially beautiful but they hav a lack of harmony, it's broken by humans. Therefore, this world is so unsteady and unstable. Reading the memoirs of contemporaries, you can feel the quivering feeling of the artist towards animals. Here are some of them: «Living in Zaraysk, close to nature, - N.N. Alekseeva writes, - I had the opportunity to observe Golubkina's strong love for her native nature. Nature included a vast world of images, in her opinion. In each tubercle, in each gully, there was a special charm for her. And she spoke about nature as about something especially expensive» ${ }^{10}$. Her attitude towards animals was really touching, «she saw in them not servants but friends of humans, she looked for a soul in them and never offended them, - N.N. Golubkin was recalling - the brother of the artist. The cruel attitude of human towards animals to the depths of her heart perturbed her» ${ }^{11}$. Animal sculptor V.V. Trofimov recalled: «Anna Semenovna was madly in love with horses, she even avoided riding in cabs, only in case of emergency, and preferred to ride on a tram ${ }^{12}$.

Here are the meaning, the depth of the artist's worldview regarding to nature, animal, and it seems incredibly simple - in a piece of fluid material that has formed into a vibrant image. It's important to note that it's not the plot but the concentration of the concept, meaning, a certain symbol in the material as a whole, that characterizes the construction of compositions of impressionist sculptors and animalists Golubkina, Trubetskoy, Andreev, Domogatsky are the final link in this process.

Conclusion

Let's summarize. Animalistic works by P. Trubetskoy, N. Domogatsky, N. Andreev, A. Golubkina, unified in mood, emotional sound, plastic rhythm, on the one hand, reflected a new understanding of sculpture of the late XIX - early XX centuries, and on the other, brought fresh breath into the animalistic genre, expanding the intuitive sphere of perception of wildlife and animals. This is the meaning and novelty of impressionistic thinking. Despite the fact that animal painting of this time didn't have a large-scale

8. Vospominaniya N.YA.Simanovich-Efimovoj ob A.S.Golubkinoj [Memories of N. I. SimonovichEfimova about A. S. Golubkina], (1944). OP TG. F. 37, ed.xr. 93. 5-30.

9. Stenogramma lekcij Soyuza pisatelej v muzee-masterskoj im. A.S.Golubkinoj. 12 noyabrya $1939 \mathrm{~g}$. Ob"yasnenie k skul'pturam Golubkinoj. G.M.Motovilov [Transcript of the lectures of the writers

'Union in the Museum-workshop. A. S. Golubkina. 12 Nov 1939 Explanation to sculpture Golubkina. G. M. Motovilov], RGALI. F. 631. Op. 5, ed. xr. 251.

10. Vospominaniya N.N.Alekseevoj o skul'ptore A.S.Golubkinoj [Memories of N. N. Alekseeva about the sculptor A. S. Golubkina], 15 XII (1849)., OP TG. F. 37, ed.xr.3. 8,9.

11. Vospominaniya N.N.Golubkina o A.S.Golubkinoj [Memories of Nikolai.N. The life and creative work of A. S. Golubkina].17 IX (1847). OP TG. F. 37, ed.xr. 28.

12. Manuscript of V. V. Trofimov. Vospominanie o skul'ptore A.S.Golubkinoj [The memory of the sculptor A. S. Golubkina], OP TG. F. 37, 12 IX (1949). 32,33. 
effect, and the method of impressionist sculptors wasn't directly used by animal artists of the XX century, nevertheless, the concept of impressionistic animalistic vision was a kind of facet on the way to the figurative-plastic interpretation of the animal among works of masters of the subsequent generations. And this was contributed, first of all, by a bold search in the material, which destroyed all ideas about what sculpture should be like and the animalistic one in particular.

\section{REFERENCES}

1. Aftandilian, David. 2007. What are the Animals to Us: Approaches from Science, Religion, Folklore, Literature, and Art. Univ. of Tennessee Press, p. 343

2. Campbell, Gordon L. 2014. The Oxford Handbook of Animals in Classical Thought and Life, Oxford University Press, p. 633

3. Werness, Hope B. 2006. Continuum Encyclopedia of Animal Symbolism in World. Art, A\&C Black, p. 476

4. Margo, De Mello. 2012. Animals and Society: An Introduction to Human-Animal Studies. Columbia University Press, p. 488

5. Grén, Roni. 2017. The Concept of the Animal and Modern Theories of Art. Routledge, p.164

6. Petrov, V. 1864 . On svetopisi in General and in particular in Russia, In Severnoe siyanie. Russkij hudozhestvennyj al'bom [Northern lights. Russian art album]. Saint-Petersburg, vol. 3, p. 3 .

7. Andreev, A. N. 1857. Zhivopis' $i$ zhivopiscy glavnejshih evropejskih shkol [Painting and painters of the main European schools ]. Saint-Petersburg, Volf's Edition, p. 579

8. Pertsov, V. (1888). The sculptor Baron P. K. Klodt In Hudozhestvennyj zhurnal. [Art magazine]. Saint-Petersburg, vol.1. pp.183- 189.

9. Silkowski, K. 1892. Memories of Nikolai Ivanovich Liberiha. In Russkij hudozhestvennyj arhiv [Russian art archive]. 2. 57.

10. Alekseev B. 1939. The exhibition of artists-animalists, In iskustvo [Art], 1939. 5. pp.127-131.

11. Schmidt, I. M. 1989. Russkaya skul'ptura vtoroj poloviny XIX - nachala XX veka, [Russian sculpture of the second half of XIX-early XX century]. Moscow, Art, $302 \mathrm{p}$.

12. Kalugina, O. V. 2006. Skul'ptor A.Golubkina, [The Sculptor A. GolubkinaThe Sculptor A. Golubkina ]. Moscow, Galart, p. 245

13. Trifonova, L. P. 2002. Impressionizm v russkoj skul'pture, [Impressionism in Russian sculpture]. St. Petersburg, XXI century, p.52

14. Payne, Christopher. 1986. Animals in Bronze: Reference and Price Guide. Antique Collectors' Club, p. 424

15. Wrangell, N.N. 1911. Foreigner in Russia, In Starye gody [Old year]. July - September, p.81.

16. Bulgakov, V. F. 1969. Vstrechi s hudozhnikami. P.P.Trubeckoj, [Meetings with artists. P. P. Trubetskoy ]. Leningrad, artist of RSFSR, p. 299

17. Kamensky, A. 1974. Vernisazhi, [Vernissages]. Moscow, Soviet artist, p. 526

18. Pavel Petrovich Trubetskoy (1866-1938): Katalog vystavki [Exhibition catalogue]. (1966), The authors of the TSA. V. and comp.: L. P. Shaposhnikov, and L. V. Fadeev. Leningrad-Moscow, Soviet artist, p.16 


\section{Ирина Васильевна Портнова Кандидат искусствоведения, доцент, департамент архитектуры Инженерной академии Российского университета дружбы народов e-mail: irinaportnova@mail.ru \\ Москва, Россия}

ORCID ID : 0000-0002-9064-5288

DOI: $10.36340 / 2071-6818-2019-15-4-82-107$

\section{О смыслах и новизне импрессионистического мышления на примере русской анималистической скульптуры конца XIX- начала XX века}

В статье рассматривается русская анималистическая скульптура конца XIXначала XX века, представляющая новое пластическое мышление и образную систему. Этот важный исторический период, ознаменованный развитием русского импрессионизма в скульптуре, на анималистическую пластику оказал весьма плодотворное влияние. К этому времени анималистический скульптурный жанр, вполне утвердившийся в своей стилевой образной системе, на рубеже веков испытал нечто новое, ранее не претворяемое. Речь идет о свежем мышлении и взгляде, как на саму пластику, таки на объект изображения. Никогда ранее скульптура не была в таком «динамичном» качестве и никогда ранее звериный образ в скульптуре не воспринимался столь мимолетно. Здесь образная концепция, заключающая в себе все тонкие грани смысловой значимости анималистической пластики. Она характеризуется, прежде всего, тем, что образ начинает обретать большую символическую многозначность и содержательность. Цель статьи состоит в том, чтобы проследить этот смысл и новизну импрессионистического мышления в анималистике на примере произведений А.Голубкиной, П.Трубецкого, Н.Андреева, В. Домогацкого. Отмечается, что произведения этих мастеров, тяготеющие к «подвижной» форме и испытавшие ее любопытные метаморфозы, отражали общую концепцию скульптуры данной эпохи с ее стремлением ко всеобщему обновлению художественного языка, способствуя передаче живого дыхания жизни и открытию нового взгляда на животный мир. В этом заключалась новизна импрессионистического мышления в анималистической скульптуре, которая способствовала расширению горизонтов восприятия природного мира в искусстве.

Ключевые слова: импрессионизм, концепџия, анималистическая скульптура, материал, пластика, образ, стиль, животное, мьиление, художник

Введение. Русская импрессионистическая скульптура конца XIX - начала XX века - явление кратковременное, но очень плодотворное. Она дала новые интересные варианты пластического мышления. Наш разговор коснется анималисти- 
ческого образа, его интерпретации. Анималистический персонаж фигурировал у известных русских скульпторов того времени: А.С.Голубкиной, П.Трубецкого, В.Н.Домогацкого, Н.А.Андреева, которые были яркими представителями импрессионизма в русской скульптуре рубежа веков. Обращение к анималистическому образу для них было вполне естественным, можно сказать, закономерным. Импрессионизм, изменивший мировоззрение, нарушивший старую академическую концепцию образа, в умах скульпторов легко смоделировался на животных. Звери и птицы стали изображаться в том качестве, в каком раньше они не встречались, а именно как носители подвижной одухотворенной материи. Эта «одухотворенная материя», которая имела место в разные эпохи, сформировала определенный интерес к анималистике как в среде русских, так и зарубежных исследователей. Авторы охотно освещали историю мирового анималистического искусства, начиная с древности и до наших дней. David Aftandilian [Aftandilian, 2007], Gordon Lindsay Campbell [Campbell Gordon, 2014], Hope B. Werness [Werness, 2006] отмечают его значимость, и ту роль, которую животные играли в обществе. Они говорят о символической сущности зверей и птиц в различных мировых культурах и указывают на все возрастающую проблему, связанную со взаимодействием человека и животных. Так, Margo De Mello [Mello, 2012] рассуждает об этих взаимоотношениях, определяет место животных в социальных и культурных мирах, полагая, что это быстро растущая область исследований актуальна для современного общества. Продолжая разговор, Roni Grén [Grén, 2017] рассматривает значение животного в теории современного искусства, делая акцент не столько на их изображении, сколько на понимание их сущности в современную эпоху.

В наше время зарубежные и отечественные исследователи подчеркивают необходимость изучения данного искусства, представляющих неизменные классические образцы.

Русские авторы охотно писали о художниках и их произведениях Нового времени, оценивали анималистический жанр как перспективный, взаимодействующий с другими жанрами, а творчество художников достойное внимания. Так, об искусстве «зверописи»XVIII века, как об особом «роде», о художниках, достигших вершин творчества, писали В.Петров [Петров, 1864], А.Н.Андреев [Андреев, 1857], Д.А.Ровинский [Ровинский, 1985]. В конце ХІХ - начале ХХ века, в связи с зарождением искусствоведческой науки, интересом к разным темам изобразительного искусства, коллекционированием произведений, устройством аукционов, деятельностью художественных музеев, все чаще стали затрагивать вопросы творческой индивидуальности художников, разных способов интерпретации образа животного. В это время вышли книги о художниках-анималистах, статьи в сборниках, журналах, словарях. Так, творчество скульпторов-анималистов: П.К.Клодта [Перцов, 1888: 183-189], Н.А.Либериха [Шилковский, 1892], рассматривалось в художественно-исторических журналах: «Художественный журнал» «Русский художественный архив». Публикации, отмеченные интересом к эстетической сторо- 
не произведений мастеров, стремлением к оценке их творчества, говорят о важной особенности работы анималиста - рисовании с живой натуры. С начала XX века результатом участия художников-анималистов на выставках, явились многочисленные каталоги. 1930-50-е годы характеризуется появлением первого каталога выставки художников-анималистов (1939), проходившей в Московском зоопарке, приуроченной к 75-летию его деятельности, и первой публикацией Б.Алексеева об этой выставке в журнале «Искусство» [Алексеев, 1939:127-131], отметившего плодотворное развитие жанра в скульптуре. В последующее время (1960-80-е) каталоги анималистических выставок станут традицией, что наглядным образом подчеркивает стойкий интерес в среде художников и общественности, как объективной сложившейся реальности.

Вопросы импрессионистической пластики не имеют столь широкого освещения в литературе. Тем не менее, творческая индивидуальность А.Голубкиной, П.Трубецкого, С.Коненкова и других мастеров рассмотрена в книге И.Шмидта [Шмидт, 1989.] Автор видит в импрессионизме последовательное и эволюционное начало. Он склоняется мысли, что импрессионизм явился результатом реалистического отображения жизни предшествующего времени, являя закономерное звено в историческом процессе. В этой связи стоит указать на монографию О.В.Калугиной, глубоко исследующей творчество знаменитого скульптора конца XIX - начала XX века А.С.Голубкиной в контексте данной эпохи [Калугина, 2006]. Несмотря на то, что А.С.Голубкина не являлась художником-анималистом в прямом смысле этого слова, ее немногочисленные анималистические произведения наряду с работами Н.А.Андреева, В.Н.Домогацкого, весьма показательны. Интуитивное переживание и прочувствование образа, свойственные методу художницы, привели к формированию нового взгляда на животных, эмоционально близких человеку, того взгляда, который получит яркое претворение в творчестве художника-анималиста XX века В.А.Ватагина. О богатых пластических возможностях импрессионистической скульптуры в свою очередь писала Л.Трифонова [Трифонова, 2002.].

Исследователи единодушны в отношении значимости импрессионизма, как сущностного явления в развитии русской скульптуры. Характеризуя творчество известных мастеров, они отмечают новый взгляд на пластику, сформировавший новое направление. Знаменательно, что Голубкина, Трубецкой, Андреев и другие, расширив границы образного понимания портрета, бытового жанра, реализовали свое творческое кредо и в анималистике. Christopher Payne [Payne Christopher, 1986.] в своей книге «Animals in Bronze: Reference and Price Guide». упоминает Трубецкого как талантливого художника-анималиста, чье имя простирается за пределы русского искусства. Однако этот аспект не нашел должного отражения в литературе, а между тем импрессионизм в анималистической скульптуре - явление необычное, «живое», национальное. В этой связи необходим более емкий анализ анималистических произведений Трубецкого и других мастеров, работав- 
ших в этой сфере, чтобы дать целостную картину развития русской скульптуры конца XIX - начала XX века.

Нас интересует импрессионизм как смысловая категория и как «смысл» реализуется в анималистической скульптуре, обладающей специфическим характером. Новый смысл порождает новую конкретную форму. Проследить эти тенденции рубежной эпохи составляет цุель настоящей статьи.

В решении поставленной цели, как наиболее целесообразный выделим метод искусствоведческого анализа, который предполагает историко-проблемный подход (проблемы импрессионистического мышления в анималистике) и историко-художественный, позволяющий выявить структуру художественного образа.

Если понимать, что импрессионизм - это движение, мышление мобильное, тем более, смысловая категория будет подвижной, базироваться на нюансах и тонких смыслах. Такой была импрессионистическая анималистическая пластика. В этой связи рассмотрим три вопроса. Первый касается скульптурного смысла импрессионизма и его претворение в анималистической скульптуре, второй нацелен на отражение новизны импрессионистического мышления, третий поясняет преимущественный выбор анималистами скульптурной модели.

\section{Образ животного в русской анималистической скульптуре кониа XIX- начала XX века}

Чтобы понимать сущность анималистики рубежа веков, заглянем в историю. Анималистическое искусство сформировалось в XVIII веке на волне общего подъема русской культуры и новых тенденций светского искусства. В петровское время большой спрос и интерес к материальным проявлениям жизни, их изучению привел к первым объяснениям природы, что отразилось в собирательстве природных объектов - «натуралей» и их зарисовках. Они и составили коллекцию раннего естественнонаучного музея - Кунсткамеры в Санкт-Петербурге. Затем, когда обозначились мастера-анималисты, а это были иностранные художники, (первый среди них, немец И.Ф.Гроот), анималистическое искусство стало востребованным. Охотная тематика, натюрморты с животными и изображение разных зверей и птиц «по лесам, перелескам, болотам и на озерах и до охоты относящиеся предметы» [Врангель, 1911.] отражало пристрастия и вкусы общества того времени. Одновременно анималистика стала облекаться в жанровую форму. Это был уже самостоятельный «род» искусства в общей сложившейся жанровой системе XVIII века.

Шагнув в новое XIX столетие, жанр нашел трактовку в «иппическом» образе (изображение лошади) в разных тематических вариантах. Впервые один персонаж - конь стал предметом интереса общественности и объектом изображения у художников-анималистов. Очевидно, что исторические стилевые эпохи, какими выступили XVIII и XIX века, формировали качества образа, всю его атрибути- 
ку. Если в раннем XVIII веке иллюзорное, тщательное живописное изображение звериных сцен призвано было приковать внимание зрителя, очаровать его многообразием, экзотикой природы, то в XIX веке была реализована совсем другая идея - показать животное на службе у человека. Не случайно это столетие называют «лошадиной культурой» . От барочного, затем классицистического решения в сторону реализма - таков путь интерпретации анималистического персонажа.

А что дал рубеж веков, в каком виде предстали животные в конце XIX- начале XX века, какова оценка их человеком и искусства изображения?

Первое, на что обратим внимание - на выбор моделей. Художники не склонны изображать охотничьих животных - участников охотных сцен с соответствующей ей атрибутикой, как это было в бронзовой скульптуре второй половины XIX века у Е.Лансере, Н.Либериха, А.Обера. И лошадь в их композициях встречается не так часто. Объяснение этому простое. Данные персонажи отражали вкусы, пристрастия, характер ушедших эпох и соответствующую скульптурную стилистику. Достоверность запечатленного мотива средствами тщательно смоделированной бронзовой формы определяла достоинства произведений тех лет.

У художников конца XIX-начала XX века мы увидим домашних животных; собак, свиней, коров и жителей лесов и полей средней полосы России: лисиц, медведей, зайцев и других. Выбор продиктован новым взглядом человека на животное, как существо со своими поведенческими особенностями вне его охотничьей принадлежности. Животное является эмоциональным персонажем, поэтому оно интересное и нет необходимости смотреть на него в узком ракурсе охотника или естествоиспытателя, а стоит посмотреть глазами только художника, причем художника-гуманиста. К тому же звери и птицы, обитающие рядом с человеком, не говоря уже о домашних питомцах, дают в изобилии такой материал. Логично предположить, что новый персонаж требовал иного подхода. Однако, характер пластики все же задавал не персонаж, а принципиально другой метод работы, который заключался в переносе акцента с твердого материала на лепной, а соответственно рука виделась основным инструментом, когда «ярко выступает фактор, определяющий фактуру - индивидуальность художника, непосредственный психофизический отпечаток его личности - отмечал В.Н.Домогацкий, - и понятно, что он будет здесь ярче, чем при непосредственном (через инструмент) контакте с материалом, при рубке и резьбе» ${ }^{1}$. В каждом из этих моментов важно было уловить самое близкое впечатление от натуры, реальности, зафиксировать трепетность этой жизни. Новое впечатление и дал импрессионизм с его новым методом работы и свежим взглядом на материал.

В системе импрессионистической пластики такое подвижное существо как животное, оказалось подходящим объектом. Ценность отдельного мгновения, его

1. Article by Domogatsky V. N. Faktura i metod ee issledovaniya [Texture and method of its investigation], OP TG. F. 12. ed. xr. 43. 13. 
переходного состояния были взяты скульпторами за основу их пластических решений. Новое решение анималистических композиций привлекало, освежало восприятие. В этом суть скульптурного смысла импрессионизма вообще, возникшего как необходимость, потребность в обновлении языка скульптуры, которая к этому времени в ряде своих образцов еще культивировала академические нормы красоты. Что касается анималистики, импрессионистический ракурс и позволил взглянуть на животное в близком непосредственном восприятии, можно сказать, эмоционально-личностном. Текучая, «подвижная» пластическая форма материала давала изменчивость состояния живого существа, точного в короткий промежуток времени, а способ мягкой пластичной моделировки рождал все новые и новые ассоциации. И эти моменты поведенческие, построенные на тонких движениях взгляда животных, расслабленности или напряжения их тел, поворота головы, туловища и т.п., нашли органическое воплощение в скульптуре. Если импрессионизм как мышление и направление стал широкомасштабным явлением во французской живописи, то в русском искусстве он имело место, прежде всего в скульптуре, которая открыла новые качества интерпретации, привлекательные в этом виде искусства и, немаловажно, послужили формированию жанра анималистики XX века.

Рассмотрим изобразительный строй некоторых произведений и попытаемся обозначить те свойства значимости импрессионистического мышления во взгляде мастеров на животное.

Отметим камерный почти этюдный характер работ Трубецкого, Андреева, Голубкиной, Домогацкого. Это небольшие станковые произведения, выполненные преимущественно в бронзе, гипсе. Бронза как давний традиционный материал у импрессионистов выступила в своих новых выразительных свойствах. Она фиксировала все текучие моменты формы. Отражающая поверхность металла, блики и глубина теней создавали эффект подвижности натуры. Напротив, гипс обладает матовой структурой, но был столь же характерным материалом, так как характеризовал лепную поверхность, объемы отчетливостью впадин и выпуклостей.

Назовем работы П.Трубецкого из ряда жанрово-анималистических: «Московский извозчик» (бронза, 1898) «Анжелина с волком» (бронза, 1909), «Девочка с собакой» (гипс тонированный, 1897), «О.Я.Якунчикова на лошади» (бронза, 1913) и другие. (Илл. 1,2,3)

В этих композициях человек и животное изображаются вместе, что весьма существенно для Трубецкого, характеризует его мировоззрение. В этом единстве он видит сосредоточение главного, говорит о привязанности животных к человеку и что еще важнее о человеческом понимании животного. В его анималистических работах («Собака (сидящий сеттер), бронза, 1898-1899, «Лошадь с жеребенком» 1899, «Сибирская лайка» 1903, «Лошадь под седлом» 1898) человек не изображается, но незримо присутствует. Здесь важный момент. Ведь человек и, прежде всего, человек ответственен за судьбу животных. Прав был В.Булгаков, когда видел 
«идею Трубецкого» в понимании животных как разумных существ. По мнению скульптора, если «их правильно воспитать и освободить от страха перед человеком, то они прекрасно будут уживаться и с людьми, и между собой». [Булгаков, 1969.]. Приверженность к вегетарианству, содержание в мастерской диких и домашних животных также объясняется фактом глубокого признания Трубецкого права на жизнь «братьев меньших» и, по сути, он является основоположником новой «концепции природы» в ее природоохранном звучании, которая в полную силу будет звучать в XX веке. А пластика, импрессионистическое выражение в скульптуре? Текучая пластическая масса, дополненная игрой света и тени на поверхности скульптур, отражает оттенки переживаний. «Лиризм» в скульптурах Трубецкого особой природы, несколько грустный и невероятно трепетный, разве только сродни с пейзажами И.Левитана. Призванный отобразить нюансы настроения, в скульптуре он как будто реализуется по своим собственным законам формообразования. Импрессионизм Трубецкого не самоцель, его лепка и приемы образной характеристики направлены в одно русло - приблизиться к постижению живой, словно ускользающей сущности живой природы. Современники видели это рациональное зерно в творчестве Трубецкого, в частности, И.И.Толстой в письме Б.Б.Голицину писал: «Художник Трубецкой, несомненно, как мне кажется, обладает недюжинным талантом, особенно удачно передает натуру в небольших фигурках, трактованных эскизно: в них он замечательно живо схватывает позу, сходство и даже экспрессию...». При этом, он видит в лице Трубецкого «талантливого живописца, знавшегося скульптурой, а не специалиста-скульптора» ${ }^{2}$. А.Каменский же полагал, что термин «живописность» по отношению к работам Трубецкого может быть применен лишь в относительной мере: мастер действительно не отшлифовывает поверхность своих скульптур, широко использует светотень, ее вибрацию, ее переходы и динамические эффекты. Но аналогия с живописью здесь, конечно, лишь внешняя: все эти приемы имеют чисто пластическую природу; объемную стереометрию скульптуры они не нарушают, а лишь расширяют и обогащают традиционный репертуар ее выразительных средств» [Каменский, 1974.]. Сам же мастер говорил: «Я люблю жизнь, не засушенную научными домыслами» [Павел Петрович Трубецкой, 1991.]. «Не засушенность» и объясняет выбор Трубецким небольших размеров скульптуры и живой пластики, словно сотворенной на глазах у зрителя.

Восприятие живописного языка в скульптурной композиции рубежа веков вполне закономерный процесс. Во-первых, скульптура импрессионизма видела в этом широкую потребность в обновлении пластического языка, который на рубеже веков стал необходимостью. Во-вторых, подвижная живописность масс, рождающая эмоциональность, отвечала анималистическому образу, способствовала проникновению в тонкий мир чувств. На такое взаимодействие указывала О.В.Ка-

2. Tolstoy Ivan Ivanovich (1900-e). Pis'mo Borisu Borisovichu Golicinu [A Letter to Boris Borisovich Golitsyn] Petersburg. OR RNB. F. 781,. ed. xr. 650. 
лугина». [Калугина, 2006.], говоря о произведениях, которые зрительская аудитория воспринимала как непривычные, но современные и духовно близкие в силу открытости мастеров скульптуры воздействию со стороны других видов искусства.

Подвижную скульптурную массу, рождающую ощущение жизни натуры, можно наблюдать в работах В.Н.Домогацкого («Коровы в стаде» 1903, «Свинья» 1909, «Телята» 1900-е все бронза, «Куры» 1900-гипс). И у Н.А.Андреева («Лисица» 1903, гипс, «Голова козленка» 1910-11, гипс, «Скованный лев» 1916, терракота). (Илл. 4,5)

Пройдя школу С.М.Волнухина, при Московском училище живописи, ваяния и зодчества, мастера уяснили принцип «натурного реализма» и отобразили его в пластике импрессионизма, находя возможность показать животное в непосредственном виде, когда образ рождался мгновенно. Отсутствие предварительных зарисовок и эскизов, всех принятых в академической школе последовательных ступеней работы - таков принцип импрессионистического восприятия, рождающий образ на ходу без каких либо повторов.

У Андреева процесс рождения скульптурного образа лежит целиком в плоскости натуры и определяется широтой его цельной линии. Вот что ученица Н.П.Гортынская записала в своем дневнике: «Наши занятия начались лепкой с живой натуры в большом светлом классе. На высокой подставке стояла клетка с петухом и курами, потом их сменяли гуси, обезьянка Яшка, лисица, медвежонок....Николай Андреевич рисовал обычно одной широкой, пластичной линией, охватывая натуру с головы до ног, быстро, энергично помечая углем светотень, слегка растирал ее пальцем - рисунок получался выразительный и объемный» ${ }^{\square}$

Ту же широкую пластичную линию можно наблюдать в прислушивающейся и смотрящей в даль лисице (1903), более трепетную в голове козленка (1910-11). В зверях Андреева нет нежного соучастия и любви к человеку, как это наблюдалось у Трубецкого, в них больше чисто природной первозданности. Ракурс психолога, который так оригинально и сполна проявился у Андреева в его знаменитой «Лениниане», спроецировался на животное. В этом отношении выделим раннюю работу И.С.Ефимова «Тигрица» $(1915$, гипс). (Илл.6)

Она как будто выступает олицетворением зарождающейся физической и энергетической силы, она ее символ, структура звериной плоти, так стихийно выявленная зорким глазом мастера. Пластика пружинистого, крепкого тела тигрицы, словно готовящегося к прыжку, больше чем импрессионистическая в традиционном понимании этого слова. Нечто схожее находим и в работах А.Голубкиной: «Собаки» (1894,), «Слон» (1901, бронза), «Обезьяна» (1901), «Лисичка» (1902), «Коты» (1909), «Лошади» (1909), «Птица» (1910), «Баран» (1913, гипс), «Тюлень» (1913, гипс). (Илл. 7,8)

Они также сложны по своей эмоциональной окраске и экспрессивны по пластической форме. Кажется, и животным тесно в этой пластической массе и они готовы вырваться наружу, причем это ощущение создается при их внешней ста- 
тичности. Волнение художника, как и в других работах Голубкиной ощутимо. Ю.Н.Верховский в стихотворной форме отразил творческий порыв мастера, словно созерцая ход этого процесса: «Грубые руки, что глыбы зеленые глины швыряли, нежным касаньем пальцев ласканье; ткань тончайших усилий ударом одним сокрушали...» . Вот что писала сама Голубкина, делясь секретами мастерства с учениками: «Когда вы работаете, надо это чувствовать, и когда вы оторвете не то, что нужно от глины, вы ей наносите рану...Нужно себя дисциплинировать, чтобы мысль, которую вы хотели выразить в глине, не теряя своей свежести, была законченной, а каждое лишнее прикосновение делает ее не свежей, затоптанной» ${ }^{3}$. З.Д.Клбукова точно характеризовала манеру Голубкиной, которая «закан-

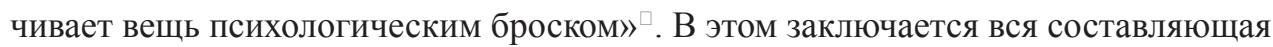
суть ее скульптурного видения. «Психологический бросок» - это динамичная масса и Анна Семеновна часто сравнивала эту динамику с динамикой идущего паровоза» - отмечала скульптор 3.Д.Клобукова. Столь же точную характеристику дает Н.Я.Симанович-Ефимова: «Скульптура Анны Семеновны - это не осязание, это - зрение. Анна Семеновна в жизни не была человеком осязающим. Она была смотрящим...». «Когда вы смотрите на предмет,- говорила художница, - пусть он попадет вам сперва в глаз, затем в сердце, а затем в голову» ${ }^{4}$.

Эта триада восприятия, описанная самим скульптором, раскрывает суть ее образного мышления, метод работы и отношение к модели. Человек и животное целый мир со своим мироустройством, а животные в концепции Голубкиной изначально красивы, но им не хватает гармонии, она нарушена человеком. Поэтому так зыбок и неустойчив этот мир. Читая воспоминания современников, можно ощутить трепетное чувство художницы к животным. Вот некоторые из них: «Живя в Зарайске, вблизи от природы, - пишет Н.Н.Алексеева, - я имела возможность наблюдать горячую любовь Голубкиной к родной природе. Природа заключала для нее необъятный мир образов. В каждом бугорке, в каждом овражке скрывалось для нее какое-то особое очарование. И говорила она о природе как о чем-то особенно дорогом» . Трогательным было ее отношение к животным, «она видела в них не слуг, а друзей человека, искала душу в них и никогда их не обижала, - вспоминал Н.Н.Голубкин - брат художницы. Жестокое отношение человека к животным до глубины сердца возмущало ее» ${ }^{5}$. Скульптор-анималист В.В.Трофимов вспоминал: «Анна Семеновна безумно любила лошадей, она даже избегала ездить на извозчиках, разве только в случае крайней необходимости, а предпочитала ехать в трамвае.» ${ }^{6}$.

3. Vospominaniya N.P.Gortynskoj o skul'ptore N.A.Andreeve [Memories of Nikolai.P.Gorchinskiy about the sculptor N. And.Andreyev], OP TG. F. 86, ed. xr.718 .2,5,34.

4. Verkhovsky Yu. N. Vayatel'. Stihotvorenie [Sculptor. Poem], RGALI. F. 202. op.2. ed. xr. 279.

5. Vospominaniya skul'ptora Z.D.Klbukovoj ob A.S.Golubkinoj [Memories of the sculptor Z. D. Klobukova about A. S. Golubkina], 30VII (1949). OP TG. F. 37.ed.xr.53. 10, 11.

6. Vospominaniya N.N.Alekseevoj o skul'ptore A.S.Golubkinoj [Memories of N. N. Alekseeva about the sculptor A. S. Golubkina], 15 XII (1849)., OP TG. F. 37, ed.xr.3. 8,9. 
Здесь смысл, глубина мировидения художницы в отношении природы, животных и выражен этот смысл, кажется, невероятно просто - в куске текучего материала, сформировавшегося в живой трепетный образ.Важно отметить, что не сюжет, а именно концентрация понятия, смысла, некого символа в материале в целом, характеризует построение композиций скульпторов-импрессионистов и анималистика Голубкиной, Трубецкого, Андреева, Домогацкого - завершающее звено в этом процессе.

Подведем итог. Анималистические произведения П.Трубецкого, Н.Домогацкого, Н.Андреева, А.Голубкиной, единые по настроению, эмоциональному звучанию, пластическому ритму, с одной стороны, отразили новое понимание скульптуры конца XIX - начала XX века, а с другой, внесли свежее дыхание в анималистический жанр, как бы расширив интуитивную сферу восприятия живой природы и животных. В этом смысл и новизна импрессионистического мышления. Несмотря на то, что анималистика этого времени не имела широкомасштабного действия, и метод скульпторов-импрессионистов не был напрямую использован художниками-анималистами XX века, тем не менее, концепция импрессионистического анималистического видения явилась своеобразной гранью на пути к образно-пластической трактовке зверя у мастеров последующего поколения. И способствовали этому, прежде всего, смелые поиски в материале, которые разрушили все представления о том, какой должна быть скульптура и, анималистическая, в частности.

\section{БИБЛИОГРАФИЯ}

1. Aftandilian, David (2007). What are the Animals to Us: Approaches from Science, Religion, Folklore, Literature, and Art. Univ. of Tennessee Press, 343 p.

2. Campbell, Gordon L.(2014). The Oxford Handbook of Animals in Classical Thought and Life, Oxford University Press, $633 \mathrm{p}$.

3. Werness, Hope B. (2006). Continuum Encyclopedia of Animal Symbolism in World. Art, A\&C Black, $476 \mathrm{p}$.

4. Margo, De Mello. (2012). Animals and Society: An Introduction to Human-Animal Studies. Columbia University Press, $488 \mathrm{p}$.

5. Grén, Roni.(2017). The Concept of the Animal and Modern Theories of Art. Routledge, $164 \mathrm{p}$.

6. Петров. В. О зверописи вообще и в особенности на Руси // Северное сияние. Русский художественный альбом. С-Петербург, 1864 , т. 3 , с.3

7. Андреев А.Н. (1857). Живопись и живописцы главнейших европейских школ, С - Петербург, Иид. О.Вольфа, 579 с.

8. Ровинский Д.А. (1985). Подробный словарь русских граверов XVI-XIX вв. С-Петербург: Типогр. Императорской Академии наук, 720 с.

9. Перцов В. Скульптор барон П.К.Клодт . Художественный журнал. С-Петербург, 1888, т.1, с.183- 189.

10. Шилковский К. (1892). Воспоминания о Николае Ивановиче Либерихе. Русский художественный архив. Вып. 2, с.57.

11. Алексеев Б.Выставка художников-анималистов. Искусство, 1939, № 5, с. 127-131.

12. Шмидт И. М. (1989). Русская скульптура второй половины XIX - начала XX века, Москва., Искусство. 302 с.

13. Калугина О.В. (2006). Скульптор А.Голубкина, М., Галарт. 245 с. 
14. Трифонова, Л. П. (2002). Импрессионизм в русской скульптуре, СПб, Петербург - ХХІ век. 52 с.

15. Payne, Christopher (1986). Animals in Bronze: Reference and Price Guide. Antique Collectors' Club, $424 \mathrm{p}$.

16. Врангель Н.Н. (1911). Иностранцы в России. Старые годы, июль - сентябрь, с.81.

17. Булгаков В.Ф. (1969). Встречи с художниками. П.П.Трубецкой, Л., Художник РСФСР, 299 c.

18. Каменский. А. (1974). Вернисажи, М., Советский художник, с.94.

19. Павел Петрович Трубецкой (1866-1938): Каталог выставки. 1966, Авторы вст. ст. и сост.: Л.П. Шапошникова и Л.В. Фадеева. Л.-М. Советский художник, 16 с. 